\title{
Salvaging and secularizing the semantic contents of religion: the limitations of Habermas's postmetaphysical proposal
}

\author{
Maeve Cooke
}

Received: 17 March 2006 / Accepted: 30 March 2006 /

Published online: 16 November 2006

(C) Springer Science+Business Media B.V. 2006

\begin{abstract}
The article considers Jürgen Habermas's views on the relationship between postmetaphysical philosophy and religion. It outlines Habermas's shift from his earlier, apparently dismissive attitude towards religion to his presently more receptive stance. This more receptive stance is evident in his recent emphasis on critical engagement with the semantic contents of religion and may be characterized by two interrelated theses: (a) the view that religious contributions should be included in political deliberations in the informally organized public spheres of contemporary democracies, though translated into a secular language for the purposes of legislation and formal decision making and (b) the view that postmetaphysical philosophy should seek to salvage the semantic contents of religious traditions in order to supply the evocative images, exemplary figures, and inspirational narratives it needs for its social and political projects. With regard to (a), it argues that the translation requirement impairs the political autonomy of religious believers and other metaphysically inclined citizens, suggesting that this difficulty could be alleviated by making a distinction between epistemologically authoritarian and non-authoritarian religious beliefs. With regard to (b), it argues that the salvaging operation is not as straightforward as Habermas seems to suppose and that social and political philosophy may not be able to tap the semantic power of religious traditions without relying on metaphysical assumptions; it concludes that, here, too, a distinction between authoritarian and non-authoritarian approaches to knowledge and validity may be useful.
\end{abstract}

Keywords Habermas · Religion · Postmetaphysical thinking · Public sphere · Semantic resource

In a number of recent essays Jürgen Habermas examines the relationship between religion and philosophy, in particular, between religion and those modes of social and

M. Cooke $(\bowtie)$

School of Philosophy, University College Dublin, Belfield, Dublin 4, Ireland

e-mail: maeve.cooke@ucd.ie 
political philosophy that are guided by what he calls a "postmetaphysical" impulse. ${ }^{1}$ In the present context, the most important feature of postmetaphysical thinking as understood by Habermas is its agnosticism with regard to the validity of religious beliefs. This agnosticism is based on the theses that philosophical truth claims - like the truth claims of science and universalist morality - must be capable of being supported publicly by reasons that everyone, everywhere could come to accept and that religious convictions are not capable of being supported publicly by such reasons. A second important feature of postmetaphysical thinking, closely related to the first, is its rejection of ideas of transcendence in a metaphysical, "otherworldly" sense; accordingly, the reference point for its claims to validity is not something beyond human practices and human history, but internal to them. This is not to say that postmetaphysical thinking rejects transcendent reasoning. To the contrary, it is crucial to Habermas's project of a critical theory of society that postmetaphysical reason has a context-transcending power that enables it to call into question the specific practices, judgments, and standards of validity that prevail in any given sociocultural context at any particular time. ${ }^{2}$ Importantly, however, the source of its context-transcending power is not metaphysical but "innerworldly"; this is why Habermas describes the context-transcending power of postmetaphysical reason, which he claims is immanent to the communicative practices of everyday life, as "transcendence from within". 3 Given Habermas's advocacy of postmetaphysical thinking, with its agnosticism regarding the truth of religious beliefs and its innerworldly character, one might expect him to be dismissive of religious language, religious teachings, and religious practices. In the early 1980s this appeared to be the case. In The Theory of Communicative Action, published in German in two volumes in 1981, Habermas presents the disenchantment and disempowering of the domain of the sacred as an unequivocal gain for humanity. (See, for example Habermas, 1987, p. 77). By the end of that decade, however, he occasionally acknowledges the - at least, temporary-importance of religion as a semantic resource for postmetaphysical philosophy. For example, in the concluding passage of a 1988 essay he remarks that even postmetaphysical thinking will be able "neither to replace nor to repress religion, so long as religious language is the bearer of a semantic content that is inspiring and even indispensable"; to be sure, he also hints that its indispensability might be the result of a deficiency in the explanatory force of philosophical language that might someday be overcome. (Habermas, 1992, p. 51.) Around this time, in a discussion with philosophers of religion and theologians, he displays similar signs of a cautious openness to the relevance of religion for postmetaphysical thinking: here he observes that the process of critical appropriation of the essential contents of the major religious traditions is still in train and that its results are hard to foresee (Habermas, 1991, p. 141). His willingness to allow for the continuing relevance of religion is coupled, however, with an insistence that postmetaphysical philosophy cannot engage with questions relating to the validation of religious truth claims: instead, postmetaphysical philosophy may make use of the semantic resources of religion only if it translates these contents into a neutralizing language and adopts an attitude of "methodological atheism" with regard to their validity. (pp. 136-139).

\footnotetext{
1 See Habermas (2003a, 2005a) For Habermas's account of postmetaphysical thinking see Habermas (1992).

2 Habermas (1996). pp.1-9. See also Cooke (1994, 2006a).

3 Habermas (1991, pp.127-156) In Habermas (1996), he refers to the power of communicative reason as "innerworldly transcendence" (p. 5).
} 
Scattered remarks of this kind from his writings of the late 1980s herald a shift in Habermas's position that is evident in a number of essays dealing with religion in relation to postmetaphysical thinking that have appeared in the past 5 years. ${ }^{1}$ The tone of these essays is noticeably less cautious concerning the question of the importance of religion as a semantic resource. Moreover, the change in tone is accompanied by a new call for the inclusion of contributions expressed in religious language in public debates in contemporary democracies. (See Habermas, 2005b). He now makes a plea for a post-secular, democratic, public sphere in which participants in discussion would be open to the cognitive contents of religious as well as non-religious contributions. This attitude of openness is required of citizens with, as he puts it, light metaphysical baggage, as well as of citizens who are metaphysically more heavily burdened. (See Habermas, 2005g, p. 270). secularly minded citizens are required to adopt a self-critical attitude towards the limits of secular rationality and strive to be open to the power of religious reasons; religiously minded citizens are required to acknowledge the secular basis of political authority and to accept the validity of core liberal democratic principles such as equality and liberty. ${ }^{4}$

Habermas mentions two reasons for his shift in position (Habermas, 2003b). The first is that recent developments in biotechnology (particularly in the field of genetic engineering) threaten an instrumentalization of human nature that fundamentally endangers our understanding of ourselves as members of the human species. They raise the question of whether this instrumentalization can be countered without the semantic resources of religious thinking. The second is that the terrorist attacks by fundamentalist Islamic militants from September 11th 2001 onwards indicate a widespread disenchantment with Western models of societal modernization. They raise the question of whether a process of modernization that is in danger of de-railing can be rescued with purely secular means. It seems, therefore, that Habermas's new call for the inclusion of religious contributions in democratic deliberation is motivated in significant measure by societal developments that have led to a greater appreciation of the need for postmetaphysical thinking to draw on the semantic resources of the major religious traditions.

Habermas hints at a further motivating factor when he distinguishes his new position from John Rawls's view of the place of religion in democratic deliberation: the need to avoid a split between the identities of individual citizens as participants in political processes and their identities as religious believers. Like a number of other commentators (See for example, Cooke, 2000; McCarthy, 1994). Habermas sees this as a problem with Rawls's approach.

As is well known, in Rawls's model of political liberalism, citizens are required to leave behind their religious worldviews when they engage in deliberation and decision-making in the public, political domain. Rawls argues that in a secular state, only those political decisions can be held to be legitimate that can be justified by reasons that are generally acceptable to all ("reasonable"), citizens (See Rawls, 1993), whether they be religious believers or non-believers and whatever particular religious convictions they may hold. This principle is central to Rawls's argument in Political Liberalism. However, he modifies it in a subsequent essay by introducing a distinction between political discussions among politicians and officials concerned to formulate and justify laws and principles and political discussions in the public sphere. (Rawls, 1997). Whereas the principle applies strictly in the case of the former, he concedes

${ }^{4}$ Habermas (2005a), pp. 10-12 and Habermas (2005b), pp. 142-144. 
that it may be relaxed in the case of the latter to allow, temporarily, for religious contributions. Thus, in political discussions in the public sphere, religious and other comprehensive doctrines, on condition that they are "reasonable", may be introduced at any time, "provided that in due course proper political reasons - and not reasons solely given by comprehensive doctrines - are presented that are sufficient to support whatever the comprehensive doctrines introduced are said to support" (p. 784).

Habermas points out that Rawls's conception of public reason imposes an intolerable psychological burden on the inhabitants of liberal democratic orders, for it obliges them to divorce their identities as religious believers from their identities as democratic citizens. When they put on their citizens' caps and engage in political discussions in the public domain, participants are required to distance themselves from the comprehensive doctrines that shape their identities and on which they draw in their deliberations in all non-public contexts. In consequence, a burdensome psychological split between the public and non-public components of identity seems inevitable. Habermas rebukes Rawls for overlooking the pivotal role that religion plays in the life of religious believers. He points out that, for religious believers, religious faith is not just a doctrine with a specific content, it constitutes a source of energy that nourishes and invigorates their entire lives (Habermas, 2005b, p. 133). Concerned to avoid a psychological burden of the sort Rawls imposes, Habermas calls for a democratic public sphere in which religious and non-religious contributions would be granted an equal hearing in discussions. To be sure, his shift in position regarding the inclusion of religious contributions in processes of democratic deliberation does not extend to the "official" political sphere of democratic legislation and decision-making in which, as for Rawls, only arguments formulated in a secular language are permissible. I come back to this point below.

Habermas's call for the inclusion of religious contributions in processes of democratic deliberation not only contrasts with Rawls's model of political liberalism; it is new within the context of his own theory of law and democracy. In Between Facts and Norms, his major work in this area, first published in 1992, Habermas made no reference to the public discussion of religious convictions. Strikingly, in his discussion of the various types of public discourses that feed into democratic legislative and decision-making processes, religious discourses - or discourses in which religious contributions play a key role-are not mentioned (Habermas, 1996, pp. 157-168). This is particularly noteworthy in light of the fact that the book makes use of a conception of discourse that is considerably more generous than the one found in The Theory of Communicative Action. In that work, Habermas had restricted the category of discourse, understood as validity-oriented, public debate guided by idealizing suppositions regarding the conduct and outcome of the debate, to discussion of claims to validity that everyone, everywhere could accept for the same reasons (Habermas, 1984). Only discussions relating to truth and to universalist morality were deemed to fall into this category. In an essay first published in 1991, however, Habermas outlines a model of practical reason that allows for ethical-existential discourses (and, indeed, pragmatic discourses) in addition to moral ones (Habermas, 1993). By introducing the category of ethical-existential discourses, he expands the framework of his discourse theory to allow for validity-oriented, public debate on matters relating to what Charles Taylor calls "strong evaluations": imperatives oriented towards a goal that is posited as good for a given individual but is not reducible to subjective purposes or preferences (p. 5). Between Facts and Norms goes even further by extending the category of ethical discourse to include public debates on shared strong 
evaluations: in such debates, referred to as ethical-political discourses, participants seek to clarify their collective goals and collective self-understandings (Habermas, 1996, pp. 96-97). Importantly, however, Habermas retains a sharp distinction between ethical discourses and moral discourses. In his account, moral discourses are concerned with the justification and application of norms that stipulate reciprocal rights and duties; they aim towards reaching universal agreement concerning the universalizability of interests (Habermas, 1991, p. 149). Ethical discourses, by contrast, involve the hermeneutical clarification of individual and collective self-understandings and clinical questions of a happy or "not-failed" life; they aim to provide advice concerning the correct conduct of life and the realization of personal or collective life-projects (Habermas, 1996, pp. 8-9); the orientation towards validity built into ethical discourses is construed as a concern to arrive at an outcome that is not universally valid but holds only "for me" or "for us" as members of a particular collective. (Habermas, 1991, p. 149).

Habermas's silence in Between Facts and Norms regarding public discussion of religious convictions may be connected with the fact that religious validity claims do not fit easily into either the category of moral discourses or the category of ethical discourses: indeed, they seem to undermine the categorial distinction between universal and non-universal validity claims on which his distinction between the two categories of discourse is based. For Habermas, universal validity claims are claims that could be accepted by everyone, everywhere for the same reasons ${ }^{5}$ evidently, he regards moral claims as being of this kind; theoretical and empirical truth claims, too, are deemed to belong in this category. Non-universal validity claims are claims that could win only local acceptance because they are tied to the particular perspective of an individual or collective; evidently, he regards ethical validity claims are being of this kind; aesthetic validity claims, too, are deemed to belong in this category. The case of aesthetic validity claims is especially relevant since Habermas appears to base their non-universality on a world-disclosing function that he also attributes to religious claims. ${ }^{6}$ Drawing on the writings of Albrecht Wellmer, Habermas links aesthetic validity claims to experiences that show us the world in a new way, potentially changing every aspect of our everyday life. ${ }^{7}$ This world-disclosing function creates problems so far as their universal acceptability is concerned. In order for aesthetic validity claims to be universally acceptable, everyone, everywhere would have had to have undergone a similar world-disclosing experience that resulted in their seeing the world in a similar new way. Furthermore, this similar experience would have to be translatable into a mutually intelligible language of justification. As I argued some years ago, the difficulties involved in meeting these conditions mean that aesthetic validity claims are unsuitable candidates for inclusion in Habermas's category of universal validity claims. ${ }^{8}$ Since Habermas also

\footnotetext{
5 In the context of Habermas's discourse theory, "universal acceptability" means, at a minimum, acceptance by all participants in an argumentative procedure (discourse) that satisfies certain demanding conditions such as inclusion of all relevant arguments, equal opportunity to exchange arguments, shared concern to find the single right answer, etc.

6 In Habermas (1991), pp. 146-147, Habermas explicitly compares religious and aesthetic validity claims with respect to their world-disclosing function.

7 See Habermas (1998). Here, Habermas cites Wellmer's essay (1991).

8 Cooke (2001). Although I still regard my argument here as correct, I would now add that Habermas's difficulties are caused in significant part by his view that universal agreement must be actually achievable. If we give up this view and, instead, interpret "universal acceptability" as a regulative idea that has an orienting force but is not achievable in actual human practices, then it becomes
} 
attributes a world-disclosing function to religious validity claims, it may be presumed that they, too, are unsuitable candidates. However, unlike aesthetic validity claims (as Habermas construes them ${ }^{9}$ ), religious validity claims do not fit readily into the category of non-universal validity claims either. To place them in this category would be to ignore their evident universal orientation: their reference to a truth that holds for everyone, everywhere. ${ }^{10}$ In sum, religious validity claims destabilize the very distinction between universal and non-universal validity claims.

At no point has Habermas explicitly drawn this conclusion; nor has he acknowledged its implications for his discourse theory of democratic deliberation. He has, however, drawn attention to the dilemma it creates for theology that is sympathetic to postmetaphysical thinking (Habermas, 1991, pp. 128-148). In his discussion with philosophers of religion and theologians in the late 1980s he makes the point that however sympathetic theology may be to this kind of thinking, it cannot adopt the attitude of methodological atheism appropriate for postmetaphysical philosophy in its dealings with religious validity claims. If it is to be faithful to its own identity, theology is obliged to see the claims to validity raised for religious teachings as analogous to truth claims: as validity claims that are universal in reach, capable of being supported by reasons that everyone, everywhere could accept. If it were merely to "cite" religious experiences, leaving aside the question of their truth or lack of it, it would have to give up its claim to absolute validity: to a form of validity that transcends all merely local evaluative contexts (p. 140). Consequently, Habermas sees only two avenues open for a theology inclined towards postmetaphysical thinking. Either the "protestant" avenue of appeal to a source of religious insight independent of reason or the "enlightened catholic" avenue of appeal to an experiential basis tied to the language of a particular tradition and susceptible to evaluation only within this tradition. In the first case, theology severs the link between truth and argumentative justification, which is one of the fundamental premises of postmetaphysical thinking. In the second case, theology denies to religious arguments any claim to context-transcending validity, thereby calling into question the theological enterprise's reference to truth.

In other words, in Habermas's work, at least up to and including Between Facts and Norms, religious and theological validity claims pose the problem that they assert universal validity for propositions and norms on which universal, discursively reached agreement seem unattainable in practice. This inhibits any rational discussion of their claims to validity in processes of democratic deliberation that accept the premises of postmetaphysical thinking. Ethical validity claims, by contrast, are deemed to be open to rational discussion, on the proviso that such discussion is confined to hermeneutic elucidation and interpretation and leaves aside their orientation towards validity in a universal sense. ${ }^{11}$ Habermas does not see this suspension of the question of ethi-

\section{Footnote 8 continued}

considerably easier to accommodate validity claims with a world-disclosing function in Habermas's schema of universal validity claims. See my discussion of regulative ideas in Cooke, 2006a.

9 Questions may justifiably be raised as regards Habermas's characterization of aesthetic validity claims as non-universal. Certainly, his position is at odds with Immanuel Kant's views on the universality of aesthetic judgments. See Kant (1987).

10 In Habermas (1991), Habermas shows signs of acknowledging this universal orientation. See my discussion in Cooke (2001b) pp. 235-236.

11 For an argument supporting the universality of ethical validity claims, see Cooke (2006a). As a general rule Habermas treats ethical validity claims as though they lacked any orientation towards validity in a universal sense. On occasion, however, he acknowledges their orientation towards something that 
cal truth as a problem since he takes for granted that the citizens of contemporary democracies, recognizing the plurality and intractability of ethical viewpoints, share his view that the truth content of strong evaluations is not open to public assessment and that they are not troubled by this.

As indicated, two societal factors appear to have motivated Habermas to propose the inclusion of religious contributions in processes of democratic deliberation: the instrumentalization of human nature threatened by developments in biotechnology and the perceived emptiness of Western models of modernization. In both cases, he worries that postmetaphysical thinking lacks the semantic resources necessary for an adequate response. In addition, he is concerned to avoid the psychologically burdensome split between religious identity and political identity that he sees as an unwelcome by-product of Rawls's approach to public reason. However, as we have seen, his theory of validity claims (at least up to and including Between Facts and Norms) is unable to accommodate public discussion of the truth content of religious contributions. Habermas's recent proposal invites us to consider whether he has modified his theory in order to allow for this kind of discussion, in particular, whether he has redesigned his conceptual apparatus in order to permit thematization of the truth content of propositions and norms, whose claims to truth are tied to experiences of world-disclosure.

Closer consideration of his proposal reveals that he has not redesigned his theory in this way. Instead, he endeavors to accommodate public discussion of religious validity claims within his existing conceptual apparatus by way of a distinction between validity claims, whose cognitive contents are open to critical assessment and validity claims, with whose cognitive contents postmetaphysical thinking must critically engage. This-implicit-distinction is evident, to begin with, in his restriction of public discussion of religious truth claims to informal processes of democratic deliberation.

As indicated earlier, Habermas's proposal for the inclusion of religious contributions in democratic deliberation is accompanied by a crucial qualification. Thematization of religious validity claims is held to be permissible only in the domains described by Habermas as the weak publics of civil society, which are concerned primarily with opinion-formation. In the model of law and politics presented in Between Facts and Norms, these weak publics are demarcated from the formally organized, public sphere of democratic legislation and decision-making, which comprises bodies such as the parliament and the judiciary; this sphere is concerned primarily with "will-formation and decision-making" (Habermas, 1996, pp. 304-308). The opinion-forming, weak publics and the will-forming, legislative and decision-making bodies are presented as distinct domains of public deliberation, although the importance of a permanent feedback relation between the two is emphasized. Contributions between the weak publics and the legislative and decision-making bodies are filtered by a range of political institutions and offices. His call for the inclusion of religious contributions in democratic deliberations relates solely to deliberations in the weak publics; in the legislative and decision-making bodies, by contrast, only secular reasons are permissible. In consequence, citizens who hold office in the legislative and decision-making bodies are required to formulate their contributions to discussions in secular terms. Secular reasons are reasons that are generally accessible: reasons that everyone accepts (or could

Footnote 11 continued

is held to be good unconditionally. See Habermas (1993), p. 5. He also hints at the universal moment inherent in ethical validity in Habermas (1992), p. 187. 
come to accept in a process of public argumentation). ${ }^{12}$ This gives rise to a need for translation: believers and non-believers must work together to translate the results of their discussions in the weak publics into a commonly accessible, secular language (Habermas, 2005b), pp.136-138.

The translation requirement recalls Habermas's earlier requirement of methodological atheism as the appropriate attitude for postmetaphysical thinking in its dealings with questions relating to the truth of religious validity claims. Common to both requirements is the view that religious validity claims cannot be formulated in a language that is generally accessible. Moreover, both are connected with the view that only generally accessible reasons are permissible in discursive processes of justification. As indicated above, "generally accessible" means potentially generally acceptable: reasons that participants in discourse could come to accept as valid following the unconstrained exchange of arguments as part of a cooperative search for truth; only such a view is compatible with Habermas's emphasis on the transformative power of argumentation. This emphasis in particularly evident in his account of public deliberation on moral matters; here, the argumentative process is held to transform perceptions of interests, indeed, it is held to generate the "moral point of view". 13 Interestingly, however, he seems to abandon his commitment to the transformative power of argumentation when religious contributions are involved: the possibility that secularly minded citizens could come to see the validity of religious contributions appears to be excluded from the outset. ${ }^{14}$ A number of remarks lend support to this impression: on various occasions he refers to the reasonable expectation of a lack of agreement [Dissens] that accompanies participants in deliberations to which religious contributions are admitted - an expectation that contrasts strikingly with the expectation of a reasonable consensus that, up to now, has been a cornerstone of his discourse theories of truth, morality and even law and democracy. ${ }^{15}$

It is quite clear, therefore, that Habermas rules out the possibility of public assessment of the truth of religious validity claims. It is equally clear, however, that, by contrast with ethical validity claims, he does not want to confine public discussion of religious validity claims to elucidation and interpretation of their contents. This is evident, to begin with, in his explicit distinction between ethical discourses and religious discourses. ${ }^{16}$ The passage in question makes clear that he sees no need for public engagement with the cognitive contents of ethical convictions: no cooperative endeavor to tap the semantic potential of ethical convictions is required-each citizen (or group of citizens) must themselves find a way of translating their ethical convictions into a language that is acceptable to everyone. In the case of religious convictions, by contrast, a cooperative effort is necessary because such convictions constitute a semantic resource for all citizens, believers and non-believers. The contrast with ethical claims is also evident in his repeated insistence that secularly minded citizens (and postmetaphysical philosophy) must take seriously the "rational content"

\footnotetext{
12 In Habermas (2005b), Habermas makes quite clear that by "secular" reasons he means "generally accessible reasons" (see, for example, pp. 137-138).

13 Habermas makes this quite clear in Habermas (2003c).

14 I make this point in Cooke (2006a).

15 In his writings on religion and politics, Habermas repeatedly refers to the reasonable expectation of lack of agreement [Dissens]. See, for example, Habermas (2005a), p. 11, p. 146, p. 271, p. 249.

16 In a footnote to his essay on religion in the public sphere, Habermas (2005b), p. 138, Habermas makes an explicit distinction between ethical discourses and religious discourses. 
or the "cognitive content" of religious views. ${ }^{17}$ Since, as we know, taking seriously the cognitive content of religious convictions is not a matter of critical assessment of their claims to validity, we need to consider exactly what it entails.

In attempting to ascertain what Habermas has in mind when he calls on secularly minded citizens to engage critically, in cooperation with their religiously minded fellow citizens, with the cognitive contents of religion, it is helpful to consider his view of how postmetaphysical philosophy can learn from the major religious traditions. He himself draws an explicit comparison between the willingness to learn that is required in each case (Habermas, 2005b, p. 138; 2005c, p. 255). He recommends that postmetaphysical philosophy open itself to the power of religious imagery and narratives with a view to seeing what it can salvage from these (bergen) for its own philosophical projects. As in the case of democratic deliberation, salvaging the cognitive content of religious traditions requires translation. Semantic contents count as cognitive if they can be translated into discourses in which only "public" reasons count: reasons that can be convincing beyond the boundaries of a particular community of faith. (Habermas, 2005c, p. 255). Passages such as this make clear that the envisaged critical engagement with the contents of religion is intended to produce images, intuitions, and insights that enrich the purely secular vocabulary of postmetaphysical thinking: it is not intended to cast light on the validity of religious truth claims. Examples he gives of successful secular translations reinforce the point. Marx's idea of an emancipated society is mentioned as a secular translation of Kant's idea of the Kingdom of God on Earth (Habermas, 2005c, p. 240), Hegel's concepts of "positivity", "alienation", and "reification" are described as secular versions of concepts rooted in the JudaeoChristian tradition (p. 250) and Walter Benjamin's idea of "anamnetic solidarity" is regarded as a secularization of an idea indebted to belief in the Last Judgment. (p. 250).

Evidently, therefore, Habermas has not changed his mind regarding the philosophical evaluation of religious truth claims: as in his previous writings, philosophy and religion are deemed to constitute separate universes of validity. ${ }^{18}$ The main difference between his earlier and his present position regarding the relationship between philosophy and religion is a heightened appreciation of the semantic power of religious images, exemplary figures, and narratives; this heightened appreciation finds expression in the replacement in his recent writings of the earlier term "methodological atheism" by the word "agnosticism" (Habermas, 2005b, p. 147). Nor has he changed his mind with regard to public discussion of the truth contents of validity claims with a world-disclosing function; public discussion of such validity claims is deemed permissible only in processes of democratic deliberation in which not truth but meaning is at issue. Here, the main difference between his earlier and his present position is a new sense that it may be possible to extract meanings from religious contributions that are meanings not just for individual citizens or groups of citizens but for all citizens, believers and non-believers. In sum, by distinguishing critical engagement with the cognitive contents of religious contributions from critical assessment of the validity of these contents, Habermas seeks to enable social and political philosophy to retain its commitment to postmetaphysical thinking, while at the same time asserting a concep-

17 See Habermas (2005a), p. 11, pp. 145-146, p. 271, p. 255.

18 His distinction between philosophical validity and religious validity is also very clear: in line with his earlier advocacy of methodological atheism, he continues to insist that philosophy and religion inhabit two separate universes so far as their conceptions of truth is concerned. See Habermas (2005a), p. 10 and especially the argument he develops in his essay on Kant in this collection: Habermas (2005c). 
tion of public reason that acknowledges the interconnection of political and religious identity and responding to the problem of semantic renewal.

In my view, his strategy is, in the first case, unsuccessful and, in the second, unsatisfactory. As I now argue, the translation requirement reproduces the Rawlsian split between political and religious identity on the level of democratic legislation and decision-making, giving rise to a conception of political autonomy that is biased in favor of non-believers. ${ }^{19}$ With regard to the question of semantic renewal, I argue that Habermas has not made clear how the meanings "salvaged" from religious traditions can retain their semantic power within the framework of postmetaphysical thinking.

1. In calling for the inclusion of religious contributions in processes of democratic deliberation, Habermas seeks to maintain a unity between religious identity and political identity that is lacking in the Rawlsian model of public reason. This is certainly a step in the right direction. By allowing for public thematization of the commitments and convictions that shape the identities of religious believers his proposal helps to avoid the psychological difficulties resulting from the Rawlsian conception. To be sure there is still a split between political and religious identity on the level of the formally organized, democratic legislative and decision-making process. However, on this level, the split affects far fewer people since only citizens who assume official functions and positions in the formally organized public sphere must leave behind their identities as religious believers. Moreover, it is likely to be less burdensome for such citizens, since they may be expected to accept the need to abstract from their religious identities as the price to be paid for the privilege of holding political office. Nonetheless, even on the level of formally organized legislation and decision-making, the split between political and religious identities remains cause for concern. The problem is less the psychological burden it imposes than its negative impact on the political autonomy of religious believers.

A conception of political autonomy as self-legislation through rational processes of collective will-formation is central to Habermas's model of law and politics. The basic intuition guiding this conception, which takes its inspiration from Rousseau and Kant, is that citizens should be able to see themselves, at one and the same time, as addressees of the law and as its collective authors (Habermas, 1996, p. 20). As he puts it: "Citizens are politically autonomous only if they can view themselves jointly as authors of the laws to which they are subject as individual addressees" (Habermas, 1995). Also central to his conception is the connection between authorship and argumentation: citizens can see themselves as joint authors of the laws to which they are subject only if they can see these laws as valid for reasons that prove themselves to be generally acceptable in processes of rational argumentation. ${ }^{20}$ It is important to note that "general acceptability" is understood by Habermas in a cognitive sense (Habermas, 1996, p. 101): political autonomy is based on rational insight into the validity of laws and political decisions (p. 100). To be sure, under the complex conditions of

\footnotetext{
19 For convenience I have decided to stick with the terminology of "believer" and "non-believer" that is favored by Rawls and Habermas. However, it is inaccurate and may be misleading. My discussion in this article suggests that the relevant distinction is not between believers and non-believers but between citizens who are metaphysically inclined and those who are postmetaphysically inclined.

20 A further important element of Habermas's conception is the claim that political ("public") autonomy and individual ("private") autonomy are co-original and carry equal weight. Elsewhere I argue that this "cooriginality thesis" can achieve its aims within Habermas's theory only if private autonomy is given an ethical interpretation: if it is construed as the capacity of the human individual to develop and pursue her own conceptions of the good. See Cooke (1999).
} 
modern democracies, political autonomy is mediated by political representation and is, accordingly, satisfied only indirectly and approximately. Nonetheless, it functions as a regulative idea guiding citizens in their efforts to find the right laws and to make the right political decisions.

The crucial question for our present purposes concerns the nature of the reasons on which the perceived validity of laws rests. If moral autonomy is the freedom to subject oneself to norms that are held to be valid for moral reasons and ethical autonomy is the freedom to pursue life-projects that are deemed worthwhile for ethical reasons, political autonomy must be the freedom to subject oneself to laws that are considered valid for political reasons. ${ }^{21}$ But what are political reasons? In Between Facts and Norms Habermas distances himself from his earlier writings in which he had conflated the domains of law and politics with the domain of morality and introduces a distinction between moral discourses and political discourses. ${ }^{22}$ On this new account, only moral reasons are allowed in moral discourse, whereas moral, ethical, and pragmatic reasons are permitted in political ones. These different types of reasons form a complex of practical validity claims that manifests the substantial unity of practical reason in democratic deliberation. ${ }^{23}$ Given Habermas's recent remarks on the importance of religious discourses in democratic deliberation, it seems reasonable to suppose that religious reasons, too, are part of this complex. On the other hand, political validity is held to be governed by the democratic principle, which demands general acceptability: according to this principle, only those laws and policies are valid that could be accepted by everyone concerned in their capacity as participants in a rational discourse (Habermas, 1996, pp. 107-111).

Evidently, there is a potential tension here between the plurality of types of reasons that are deemed appropriate in political discourses, the alleged lack of general acceptability of some of these types of reasons, and the posited link between political validity and general acceptability. Habermas defuses the tension by making ethical and religious neutrality a prerequisite of general acceptability: the reasons supporting the validity of laws and political decisions may contain no evaluative judgments as to the truth of ethical and religious worldviews; only such neutrality is deemed to be compatible with postmetaphysical thinking (Habermas, 2005d, p. 86). This is why he calls for the translation of religious and ethical contributions into a neutral, secular language. $^{24}$

However, if reasons based on ethical and religious worldviews are ruled out as reasons for the acceptability of laws and political decisions, the resulting conception of political autonomy is biased in favor of citizens with postmetaphysical worldviews. Only such citizens can aspire towards self-legislation on the basis of rational insight.

21 Habermas insists on the distinction between moral autonomy and political autonomy. See Habermas (2005d).

22 In Habermas (1996), p. 168, Habermas presents a model of rational political will-formation in which ethical-political discourses feed into what he calls legal discourses. In his Postscript to that work, however, he acknowledges that this schema is misleading, for political questions usually require the simultaneous treatment of moral, ethical, and pragmatic aspects (p. 565, note 3). Since, in my view, the term "political discourse" best captures Habermas's intuition, I use that term in the following.

23 Cf. Habermas's critique of Robert Alexy's alleged “moralization” of law in Habermas (1996), pp. 229-223.

24 We have seen that a cooperative translation effort is required in the case of religious validity claims, whereas responsibility for the translation of ethical worldviews is placed on the citizens who hold these worldviews. 
By contrast, citizens with what Habermas calls "heavy metaphysical baggage" are denied the possibility of attaching a cognitive sense to the laws and political decisions that they, in common with all other citizens, deem to be generally acceptable. This is because context-transcending validity, for them, has an unavoidable otherwordly aspect. At best they can regard the laws and political decisions in question as valid in the sense of congruent with the premises of postmetaphysical thinking, which they endorse, not because they are convinced of the rationality of its assumptions, but for pragmatic or strategic reasons; they cannot see the laws and decisions as valid for reasons that express their own, metaphysically based, views of validity. I develop this argument in Cooke (2006b). This implies that the regulative force of the idea of political autonomy, understood by Habermas as self-legislation based on rational insight, is significantly impaired for religious believers and for those who hold ethical worldviews of a metaphysical kind.

I have suggested that the exclusion of religious reasons from political deliberation considerably weakens the regulative force of the idea of political autonomy for those who hold religious (and other metaphysical) worldviews, hindering them from seeing themselves as authors of the laws to which they are subject. This is a source of political and social disaffection. Furthermore, since those who hold postmetaphysical worldviews are able in principle to experience its full regulative force, a fundamental inequality is built into the political order that is a further source of disaffection.

Habermas could avoid these problems by allowing for the inclusion of religious (and other metaphysical) contributions on all levels of democratic deliberation: not just in the informal, weak publics but also in the formally organized sphere of democratic legislation and decision-making. But, as we know, he vehemently rejects any such proposal, seeing it as "[violating] the principle that the powers of the state shall remain neutral in the face of competing world-views." ${ }^{25}$ Certainly, the principle of neutrality should not be given up lightly. Like Habermas, I see the institutionalization of this principle as the result of historical learning processes - accompanied by much violence and suffering - in the course of which freedom of opinion has come to be recognized as a democratic right: I too regard the secular state as a historical achievement (Habermas, 2005e, p. 322). However-and here, too, I agree with Habermas - I regard historical learning processes as essentially open-ended, maintaining that historical experiences are always subject to argumentative reinterpretation in light of new situations that arise due to factors such as changed geopolitical constellations, technological innovations, and ecological developments. Thus, I see no contradiction between the view that the secularization and democratization of political authority is a historical achievement and the view that a critical reevaluation of the need for a principle of neutrality is necessary in the historical situation in which the inhabitants of liberal democracies currently find themselves. Habermas himself acknowledges a significant change in the current historical context when he refers to Germany and other liberal democracies as post-secular societies: societies that have adapted to the fact that religious communities continue to exist in a context of ongoing secularization (Habermas, 2003b, p. 104). He also, as we have seen, highlights two features of the changed context: the instrumentalization of human nature accompanying developments in biotechnology and the insecurity caused by terrorist attacks apparently motivated by rejection of the emptiness of Western models of modernization.

25 This is his criticism of Nicholas Wolterstorff's argument in favor of allowing the use of religious reasons in political decision-making. See Habermas (2005b), p. 140, my translation. 
The new historical situation in which we currently find ourselves, together with the problems of disaffection and inequality resulting from the impaired political autonomy of religious (and other metaphysically inclined) believers, suggest that it is time to revisit the principle of state neutrality with regard to religious and ethical worldviews. To be sure, caution is required. Any attempt to reconsider the principle of neutrality must endeavor to hold onto the social, political, and intellectual advances that have resulted from the secularization and democratization of political authority. In my view, Habermas's concept of communicative rationality, which ties validity to argumentation, expresses one of these advances: a "non-authoritarian" approach to questions of truth and knowledge (Cooke, 2005, 2006a). A non-authoritarian approach to truth and knowledge denies that knowledge of truth is available independently of the linguistic practices of human agents in historically specific, sociocultural contexts. In addition, it ties knowledge of truth to argumentative justification. This entails the capacity and willingness to support one's validity claims with reasons in open-ended, inclusive, and fair processes of argumentation in which participants are motivated by the search for the single right answer. Thus, it rules out claims to have access to the right answer independently of the exchange of arguments with others. Importantly, however, it does not preclude religious or other forms of metaphysical thinking. In this regard, Habermas's view of religious thinking is too indiscriminate: he fails to distinguish between religious beliefs that are epistemologically authoritarian and those that are not. The former claim to have knowledge of truth without mediation through language, in abstraction from history and context, and independently of argumentation; the latter acknowledge the influences of language, history, and context on our knowledge of truth and make such knowledge dependent on argumentative justification. This lack of discrimination is apparent, for example, when he characterizes belief as a form of knowledge that revokes the modern philosophical differentiation between truth and certainty. ${ }^{26}$ I find it more helpful to distinguish between two alternative ways of understanding the claims to truth of religious teachings. On the first understanding, the truth of the teachings is grounded in the certainty of religious experience; the certainty of the experience, and by extension the truth of the teachings, is unshakeable and hence immune to critical challenge. On the second understanding, by contrast, the truth of the teachings is merely supported by religious experiences; these count as evidence supporting claims to validity that must be subjected to critical interrogation in argumentation. In both cases, truth itself is conceived of in metaphysical terms: as unchanging and absolute. However, the interpretations differ in their views of what kind of knowledge of truth is available to human beings. In the first case, final knowledge is held to be available; this is what I refer to as an epistemologically authoritarian position. In the second case, only fallible knowledge is held to be available; this is what I refer to as an epistemologically non-authoritarian position. In short, a metaphysical understanding of truth does not imply epistemological authoritarianism. This leads me to suggest that it is not religious or other metaphysically based viewpoints that should be excluded from processes of democratic legislation and decision-making but viewpoints that are epistemologically authoritarian.

Habermas might accept that religious belief is compatible with a distinction between the metaphysical, unchangeable, and absolute character of truth and the related

26 This is how I interpret his reference to the epistemic status of religious belief as "a de-differentiation of truth and certainty" (eine Entdifferenzierung von Wahrheit und Gewissheit). Habermas, (2002). 
concepts of unconditional validity that guide religious thinking and action and the fallible character of the knowledge of truth that is available to human beings. However, he might still object to the inclusion of any kind of religious contributions in democratic legislation and decision-making on the grounds that the justification of religious belief is a matter of revelation rather than argumentation. Presumably, his reference to the world-disclosing function of religion is to be understood in this vein. This view of the justification of religious validity claims is implicit in his characterization of religious and philosophical truth as two distinct universes of validity and in his call for critical engagement with the cognitive contents of religious contributions to democratic discussion as opposed to critical assessment of their claims to truth. On several occasions, moreover, he explicitly mentions the significance of revelation as the basis for religious conviction (Habermas, 2005c, p. 252). In discussing Kierkegaard, for example, he appears to accept his view that the "chasm between knowing and believing cannot be bridged by thought" (Habermas, 2003d, p. 10). If this is so, even a philosopher such as Kierkegaard, who accepts that our knowledge of God is limited by the finite nature of human cognition and, accordingly, may be described as epistemologically non-authoritarian, can see questions of religious truth as immune to argumentative interrogation and justification.

However, here, too, there is a need for further distinction. Habermas's view that the dependency of the truth of religious validity claims on revelation makes them immune to argumentative interrogation and justification is indicative of his tendency to conflate two issues: the ways in which we experience the force of religious truth (and, indeed, truth in general) and the ways in which the insights we acquire as a result of such experiences may be critically examined. Distinguishing the two opens the door for the argumentative interrogation and justification of religious validity claims. It enables us to see that an individual who has acquired her sense of the truth of religion by way of experiences of revelation ("world-disclosure") is not therefore necessarily unable to provide reasons in support of her religious validity claims in argumentative exchanges with others.

Habermas has only recently begun to move away from a position that made argumentation the privileged site for cognitive learning. This over-inflated view of argumentation was a corollary of his - now abandoned-constructivist account of truth and persists today in his constructivist account of moral validity (Habermas, 1973, 2003c). In these accounts, truth and justice are held to be constructed by way of the argumentative exchange of reasons under ideal justificatory conditions. His constructivist account commits him to the position that significant shifts in perception in relation to truth and justice come about by way of the intersubjective exchange of reasons. Such a view of cognitive learning is quite implausible. Shifts in perception, moral, religious, and otherwise, generally occur as a result of new experiences that are prompted by encounters with different cultures and different species, that arise out new lifesituations, that result from ecological and technological developments, and so on. ${ }^{27}$ Thus, we need to distinguish between the non-argumentative ways in which our sense of the truth of propositions, norms, and viewpoints is acquired and openness to argumentative interrogation of the validity of the propositions, norms, and viewpoints that are subsequently asserted. If we do so, we can see that revelation does not necessarily

27 Albrecht Wellmer makes this point with regard to revisions in collective moral matrices: these "do not as a rule take place only in the medium of argumentation, but under the pressure of a struggle for recognition and under the influence of new experiences. See A. Wellmer (1991b). 
rule out argumentation. Of course, the demonstration that revelation and argumentation are not incompatible does not yet say anything about the kinds of reasons that could be brought to bear in critical discussion of the truth of religious validity claims. The positive counterpart to my hitherto negative strategy calls for an account of the ways in which critics and proponents of religious beliefs could interrogate and justify the beliefs in questions. Elsewhere, I outline a model of practical reasoning that offers some hints as to what such an account would look like (Cooke, 2006a, chapter 6).

I have suggested that the above distinction, together with the distinction between epistemologically authoritarian and epistemologically non-authoritarian religious beliefs, may help to dispel Habermas's reluctance to allow for the critical assessment of the truth contents of religious validity claims in processes of democratic deliberation. The advantage of these distinctions is that they allow for the inclusion of reasons based on religious and other metaphysical worldviews in democratic legislation and decision-making without undermining the non-authoritarian impulse guiding modern processes of secularization and democratization. We might say: they make room for a post-secular state as the natural complement to a post-secular society. ${ }^{28}$ To be sure, my proposal to exclude epistemologically authoritarian contributions to the process of democratic legislation and decision-making could be seen as more stringent - and more difficult to implement - than Habermas's proposal to exclude religious contributions. I agree that the difficulties in implementing my proposal need to be considered more carefully. However, I do not agree that its alleged stringency constitutes an objection. All political orders are based on certain exclusions and restrictions: the challenge for citizens of liberal democracies is not the elimination of all exclusions and restrictions but only those that do not stand up to critical interrogation in public processes of deliberation. My contention-admittedly, not argued in sufficient detail here-is that there are good reasons for excluding authoritarian modes of thinking and acting from democratic legislative and decision-making processes, but that a blanket exclusion of religious contributions is not justifiable in the present historical context. Elsewhere, I offer reasons in support of the first part of this contention (Cooke, 2006a, chapter 6). The second part is supported by the case I make above for including non-authoritarian religious contributions at all levels of democratic deliberation. I have suggested that doing so enables (non-authoritarian) religious believers to feel the full force of the regulative idea of political autonomy, thereby removing one significant cause of disaffection for religious believers and eradicating an inequality that currently exists between religious believers and nonbelievers. It may even help religious believers who hold authoritarian views of truth and knowledge to see that religious faith is not necessarily dependent on such views, encouraging the kind of non-authoritarian approach, not just to cognition but also to ethics and politics, that I see as a cornerstone of liberal democracy.

2. There is a second problem with Habermas's proposal for a secular translation of the contents of religious traditions: he passes too easily over the difficulties involved in transposing images, figures, and narratives from a metaphysical framework into a postmetaphysical one, simply taking for granted that the transposed contents will retain a semantic power.

We will recall that Habermas sees religion as an important source of semantic regeneration for postmetaphysical thinking in general, and for normative social and political theory in particular. I have already mentioned the external, societal factors

28 I make the case for a post-secular state in Cooke (2006b). 
that, in his view, make the need for semantic renewal particularly urgent in the current historical context; in addition, there is a factor internal to postmetaphysical thinking that contributes to this urgency: its formal approach to questions of the good life. In Habermas's postmetaphysical account of ethics, this formal approach not only entails abstention from specific pronouncements regarding the content of the good life, it also implies handing over the responsibility for decisions regarding contents to the individuals and collectives concerned. Accordingly, it can be said to prioritize freedom over virtue or happiness, placing value on the ethical autonomy of individual subjects: on their freedom to develop and pursue their own conceptions of the good. This formal conception of ethics is connected with a formal conception of moral validity ("discourse ethics"), which makes the contents of moral norms and principles dependent on processes of moral discourse, and with formal conceptions of law and democracy, which makes the contents of laws and democratic decisions dependent on the deliberative procedures of citizens.

However, the formal approach advocated by postmetaphysical thinking means that ethical, moral, and political theories cannot themselves supply participants in practical deliberations with the imaginative projections of the good life and the good society that are necessary to orient and to motivate practical deliberation about the proper goals of human action. It can be argued, therefore, that such theories must look outside of their own frameworks for alternative sources of meaning when the imaginative projections on which they traditionally relied no longer provide the required orientation and motivation. In the past Habermas has been taken to task for failing to take the question of semantic renewal in critical theory sufficiently seriously (See, for example, Kompridis, 1999; Smith, 1997). His remarks on salvaging the contents of religious traditions and making them fruitful for postmetaphysical thinking indicate that he is now clearly aware of the problem and concerned to respond to it. His heightened awareness of the importance of religion as a semantic resource is particularly evident in a recent essay on Kant's struggle to give an account of the relationship between faith and knowledge. In this essay, he criticizes Kant's tendency to offer a purely instrumental interpretation of positive religion. Against this, he points out that positive religion, with its vivid exemplary figures, its inspirational stories of the lives of the saints and prophets, its promises and miracles, and its suggestive images and edifying narratives, serves as a source of inspiration for the development of philosophical theories and concepts (Habermas, 2005c, pp. 231-235). He maintains that practical reason must stir our imaginations with the help of secularized versions of such images, figures, and narratives if it is to orient and motivate human beings to work collectively towards realizing a secular version of Kant's Kingdom of God on Earth (pp. 230-231). However, here he seems to take for granted that the semantic contents of religious traditions will continue to have the power to orient and motivate our efforts to achieve a better society when released from their religious framework, maintaining that images of "not-failed forms of life" can inspire us and encourage us even without the certainty that God is waiting in the wings (p. 235).

Against this too ready presumption, I suggest that the transposition of the semantic contents of religion into a postmetaphysical framework is not as simple as Habermas seems to suppose. This is due to the dependency of the power of religious images, figures, and narratives on metaphysical assumptions. If they are to retain their semantic power, therefore, the new postmetaphysical framework must supply equivalents for these assumptions. Habermas does not acknowledge this complication. Nor can any equivalents be extracted easily from his theory.

照 Springer 
The semantic power of religious contents depends above all on two kinds of metaphysical assumptions. The assumption (a) that religious images, figures, and narratives disclose forms of life that are valid in an unconditional sense and the assumption (b) that the intentional actions of human beings can bring them closer to achieving the disclosed forms of life. If postmetaphysical thinking is to be able to tap the power of the semantic contents of religion, it must supply equivalents for these assumptions.

(a) Within a religious framework, validity in an unconditional sense (for shorthand, I shall refer to such validity as truth) refers to an otherworldly, transcendent object. The orienting and motivating power of religious images, figures, and narratives derives from their relation to this transcendent object.

In transposing semantic contents from a religious framework to a postmetaphysical one, Habermas cannot simply jettison their reference to a otherworldly, transcendent object but must supply some postmetaphysical equivalent. As we know, it is the ambition of his postmetaphysical theory to offer an innerworldly interpretation of the unconditional: to rescue its sense without recourse to God or to an Absolute (Habermas, 2002, pp. 133-146). For this purpose, he proposes a deflationary interpretation that locates the transcending power of the unconditional in the forms of communication through which we reach understanding with one another about something in the world and about ourselves (Habermas, 2003d, pp. 9-10). The success of this undertaking depends in large measure on the ability of his reconstructive analyses of communicative practices (his "formal pragmatics") to provide a secure foundation for conceptions of validity that dispense with metaphysical projections yet exert a context-transcending power. In recent years Habermas seems prepared to admit that formal pragmatics cannot on its own yield the required notions of contexttranscending conceptions of validity. ${ }^{29}$ However, he has not made clear which supplementary strategies are available to make good this deficiency. ${ }^{30}$ Until he does so, his theory cannot convincingly claim to offer an interpretation of validity in an unconditional sense (truth) that does not rely on metaphysical assumptions.

Thus, one of the tasks confronting him if he is to account for the orienting and motivating power of secularized versions of religious images, figures, and narratives is to supply a postmetaphysical conception of truth. A further task is to give an account of the relationship between truth and the disclosed forms of life that avoids the objection of epistemological authoritarianism. I have asserted that we must posit some kind of relationship between the two terms if we are to make sense of the orienting and motivating power of images, figures, and narratives: we must be able to see the forms of life they disclose as representation of truth. But there are different ways of construing the relationship. One possibility is to see the disclosed forms of life as direct representation of truth, unmediated by language, history and context. The advantage of this is that it guarantees the unconditional validity of the disclosed form of life. The disadvantage is that it is epistemologically authoritarian, for it implies that human beings have access to final, unquestionable knowledge of truth. Another possibility is to see the disclosed forms of life as an indirect representation of truth. On this account, the disclosed form of life reveals something about truth, but what is revealed is mediated through language, history and context. Evidently, only an interpretation along these lines is congruent with the premises of postmetaphysical thinking. However, if Habermas is to offer this kind of interpretation of the relation between truth and what

29 See, for example, Habermas (2000). See also Habermas (2005f).

30 I argue this point in Cooke (2006a), esp. chapters 3, 5, and 7. 
is disclosed by way of images, figures, and narratives, he will have to reconsider his position with regard to the critical assessment of ethical validity claims. For, clearly, the disclosed forms of life amount to imaginative projections of ways of living one's life and of social conditions that claim to be the best for human beings. Since they are construed, not as direct representations of truth, but as representations mediated by language, history, and context, no single projection is indisputably valid. This raises the question of how we should assess their claims to validity - a question that becomes increasingly urgent in historical contexts in which there are a plurality of competing visions of the good life and the good society (Habermas, 2005c, pp. 248-249). In other words, an epistemologically non-authoritarian account of the relationship between the disclosed forms of life and truth calls for an account of how ethical-existential and ethical-political validity claims can be assessed critically. But as we have seen, Habermas continues steadfastly to reject the possibility of the critical assessment of ethical validity claims. So long as he refuses to do so, however, he will be unable to account for the semantic power of the images, figures, and narratives he seeks to salvage from religious traditions.

(b) The semantic power of religious images, figures, and narratives depends not only on the metaphysical assumption that the form of life they disclose represents truth; it relies on the additional assumption that the right kind of intentional action will bring human beings closer to achieving the disclosed forms of life. Without an assumption of this kind, human beings would have no rational motivation for endeavoring to achieve ways of living and social conditions that are closer to the disclosed images of the good life and the good society than other ones.

In his essay on Kant, Habermas offers an insightful reading of Kant's concept of rational belief that shows great sensitivity concerning the need for such an assumption (Habermas, 2005c). Kant posits the assumption of God's presence in human history as a rational belief (Vernunftglaube) (pp. 222-232). Rational belief shares with philosophical knowledge a reference to convincing reasons, while it shares with religious faith an interest in the fulfillment of an existential hope (p. 230). The concept is introduced by Kant in response to a difficulty connected with his position that the moral law is inherently motivating, that observance of it is its own reward, and that there is no necessary connection between the happiness deserved by a morally worthy person and the actual happiness she enjoys in her life. This raises the problem of how to make sense of unjust suffering and, more generally, of the connection between moral action and moral consequences. Kant acknowledges that, as rational beings, we need to assume that God is at work in human history, since it cannot be a matter of indifference to reason whether suffering is unjust or just and whether morally good behavior leads to individual or collective happiness. Existentially, too, we need to make such an assumption in order to ward off the despair that looms when we encounter the phenomenon of unjust suffering and when evil seems to triumph over morally good action. In light of Habermas's evident appreciation of the importance of such an assumption, it is strange that he does not acknowledge the need for an equivalent in his own critical social thinking. ${ }^{31}$ As in Kant's moral theory, the question of the relation between moral action and its consequences does not arise in Habermas's moral theory, since this theory is purely deontological: it confines itself to stipulat-

${ }^{31} \mathrm{He}$ merely comments that the intuition at the heart of Kant's notion of rational belief reminds us that the morally good must be sought in the concrete good of forms of life that have been made better. See Habermas, (2005c), p. 235.

Springer 
ing what ought to be done from the point of view of a discursively reinterpreted version of Kant's moral law. Nonetheless, his evident appreciation of the problem to which Kant responds with the notion of rational belief suggests awareness that there are rational and existential gaps in his own moral theory that call for remedy by an equivalent notion. Moreover, Habermas does not only offer a deontological moral theory; he also offers a critical social theory that is concerned to point toward emancipatory potentials in everyday communicative practices that human beings, by their actions, should attempt to realize. It is of course in the context of his critical social theory as a whole that he acknowledges the importance of images, figures, and narratives in orienting and motivating human beings to work together with the aim of achieving better forms of life. The question of the relation between action and consequences cannot be a matter of indifference to that theory. It seems, therefore, that Habermas needs something like Kant's notion of rational belief, for without some such notion, he will be unable to make sense of the orienting and motivating power of the images, figures, and narratives that he seeks to salvage from religious tradition. However, congruence with the premises of postmetaphysical thinking requires him to develop a conception of rational belief that makes no reference to God or any other otherworldly, transcendent objects. Not only has he not made any attempt to do so, he has not, so far, acknowledged the need for a postmetaphysical equivalent for the notion of rational belief.

My discussion has raised questions about Habermas's proposal to salvage the contents of religious traditions for social and political philosophy within a framework that dispenses with metaphysical assumptions. On the political level, I expressed concern regarding his requirement that only contributions that have been translated into a postmetaphysical vocabulary may be considered in democratic processes of legislation and decision-making; my argument here is that a restriction of this kind results in the impaired autonomy of religious believers and that, in the case of many religious believers, this impairment cannot be justified in the present historical context; instead of a blanket exclusion of religious beliefs, therefore, I propose the exclusion of beliefs that are epistemologically authoritarian. I subsequently examined the ability of Habermas's theory to transpose the semantic contents of religious traditions into a postmetaphysical framework without compromising the power of the images, figures, and narratives concerned; here, I argue that Habermas has not yet confronted the difficulties involved. Although I did not show that he is unable to resolve them, my suspicion is that this is the case. As I argue in Re-Presenting the Good Society, ${ }^{2}$ metaphysical assumptions are unavoidable in critical social thinking; however, their unavoidability does not have to be cause for concern. In this regard, too, the distinction between epistemologically authoritarian and non-authoritarian approaches is useful. Clearly, many traditional metaphysical theories contain elitist, absolutist, and ahistorical elements that lead to epistemological authoritarianism (Cooke, 2001, pp. 70-71); as such they are out of step with the conception of "situated rationality" integral to the self-understanding of contemporary social and political philosophy and should be rejected. ${ }^{32}$ But commitment to metaphysical assumptions does not lead inevitably to epistemological authoritarianism. Jettisoning the elitist, absolutist, and ahistorical elements of traditional modes of metaphysical thinking, we can endeavor to develop non-authoritarian modes; metaphysical thinking of this kind acknowledges that its guiding assumptions are mediated by language, history, and context and understands

32 I discuss the concept of situated rationality at some length in Cooke (2006a). 
them not as indisputable claims about the structures of the mind or the world, but as arguments that raise claims to validity that can be subjected to critical interrogation in open-ended, inclusive, and fair processes of public argumentation (Cooke, 2006a, chapter 6).

\section{References}

Cooke, M. (1994). Language and reason. Cambridge, MA: MIT Press.

Cooke, M. (1999). A space of one's own: Autonomy, privacy, liberty. Philosophy and Social Criticism, $25(1), 23-53$.

Cooke, M. (2000). Five arguments for deliberative democracy. Political Studies, 48(5), 947-969.

Cooke, M. (2001a). Socio-cultural learning as a 'transcendental fact': Habermas's postmetaphysical perspective. International Journal of Philosophical Studies, 9(1).

Cooke, M. (2001b). Critical theory and religion. In D. Z. Phillips \& T. Tessin (Eds.), Philosophy of religion in the 21st century (pp. 211-243). London: Palgrave.

Cooke, M. (2005). Avoiding authoritarianism: On the problem of justification in contemporary critical social theory: International Journal of Philosophical Studies, 13(3), 379-404.

Cooke, M. (2006a). Re-Presenting the good society. Cambridge, MA: MIT Press.

Cooke, M. (2006b). Säkulare Übersetzung oder postsäkulare Argumentation? Habermas über Religion in der demokratischen Öffentlichkeit. In R. Langthaler \& H. Nagl-Docekal (Eds.), Jürgen Habermas über Religion. Wien/Berlin: Oldenbourg Verlag.

Habermas, J. (1973). Wahrheitstheorien. In H. Fahrenbach (Ed.), Wirklichkeit und Reflexion. Pfullingen: Neske.

Habermas, J. (1984). The theory of communicative action (Vol. 1), trans. T. McCarthy. Boston: Beacon Press.

Habermas, J. (1987). The theory of communicative action (Vol. 2), trans. T. McCarthy. Boston: Beacon Press.

Habermas, J. (1991). Transzendenz von innen, Transzendenz ins Diesseits. In Texte und Kontexte Frankfurt am Main: Suhrkamp.

Habermas, J. (1992). Postmetaphysical thinking, trans. W. M. Hohengarten. Cambridge, MA: MIT Press.

Habermas, J. (1993). On the pragmatic, the ethical, and the moral employments of practical reason. In Justification and application, trans. C. Cronin. (pp. 1-17) Cambridge, MA: MIT Press.

Habermas, J. (1995). Reconciliation through the public use of reason: Remarks on John Rawls's political liberalism. The Journal of Philosophy, XCll(3), 109-131.

Habermas, J. (1996). Between facts and norms, trans. W. Rehg. Cambridge, MA: MIT Press.

Habermas, J. (1998). Questions and counter-questions. In On the pragmatics of communication, edited and with an introduction by M. Cooke (pp. 403-433). Cambridge, MA: MIT Press.

Habermas, J. (2000). A Genealogical analysis of the cognitive content of morality. In C. Cronin \& P. de Greiff (Eds.), The inclusion of the other (pp. 3-46). Cambridge, MA: MIT Press.

Habermas, J. (2002). Wann müssen wir tolerant sein? Über die Konkurrenz von Weltbildern,Werten und Theorien. Festvortrag zum Leibniztag der Berlin-Brandenburgischen Akademie der Wissenschaften (im Juni, 2002).

Habermas, J. (2003a). The future of human nature, trans. W. Rehg, M. Penksy, and H. Beister. Cambridge: Polity Press.

Habermas, J. (2003b). Faith and knowledge. In Habermas (2003a), 101-115.

Habermas, J. (2003c). Truth versus rightness: On the sense of normative validity in moral judgments and norms. In Truth and justification, trans. B. Fultner (pp. 237-276). Cambridge, MA: MIT Press.

Habermas, J. (2003d). Are there postmetaphysical answers to the question: What is the 'good life?' In Habermas (2003a), 1-15.

Habermas, J. (2003e). To seek to salvage an unconditional meaning without God is a futile undertaking. In Justification and Application, trans. c. cronin (pp. 133-146). Cambridge, MA: MIT Press.

Habermas, J. (2005a). Zwischen Naturalismus und Religion. Frankfurt am Main: Suhrkamp.

Habermas, J. (2005b). Religion in der Öffentlichkeit. Kognitive Voraussetzungen für den öffentlichen "Vernunftgebrauch" religiöser und säkularer Bürger. In Habermas (2005a), 119-154.

Habermas, J. (2005c). Die Grenze zwischen Glauben und Wissen: zur Wirkungsgeschichte und aktuellen Bedeutung von Kants Religionsphilosophie. In Habermas (2005a), 216-257. 
Habermas, J. (2005d). Zur Architektonik der Diskursdifferenzierung: kleine Replik auf eine grosse Auseinandersetzung In Habermas (2005a), 84-105.

Habermas, J. (2005e). Kulturelle Gleichbehandlung - und die Grenzen des modernen Liberalismus. In Habermas (2005a), 279-323.

Habermas, J. (2005f). Vorpolitische Grundlagen des demokratischen Rechtstaats. In Habermas (2005a), 94-96.

Habermas, J (2005g). Religiöse Toleranz als Schrittmacher kultureller Rechte. In Habermas (2005a), 258-278.

Kant, I. (1987). Critique of judgment, trans. W.S. Pluhar. Indianapolis: Hackett Publishing Co.

Kompridis, N. (1999). Heidegger's challenge and the future of critical theory. In P. Dews (Ed.), Habermas: A critical reader (pp. 118-150). Oxford: Blackwell.

McCarthy, T. (1994). Kantian constructivism and reconstructivism: Rawls and Habermas in dialogue. Ethics, 105, 44-63.

Rawls, J. (1993). Political liberalism (pp. 47-66). New York: Columbia University Press.

Rawls, J. (1997). The idea of public reason revisited: The University of Chicago Law Review, 64(3), $765-807$.

Smith, N. (1997). Strong hermeneutics: Contingency and moral identity (pp. 144-169) London: Routledge.

Wellmer, A. (1991a) Truth, semblance, reconcilation. In A. Wellmer, The persistence of modernity, trans. D. Midgely. Cambridge, MA: MIT Press.

Wellmer, A. (1991b). Ethics and dialogue. In The persistence of Modernity (pp. 113-231). 